24

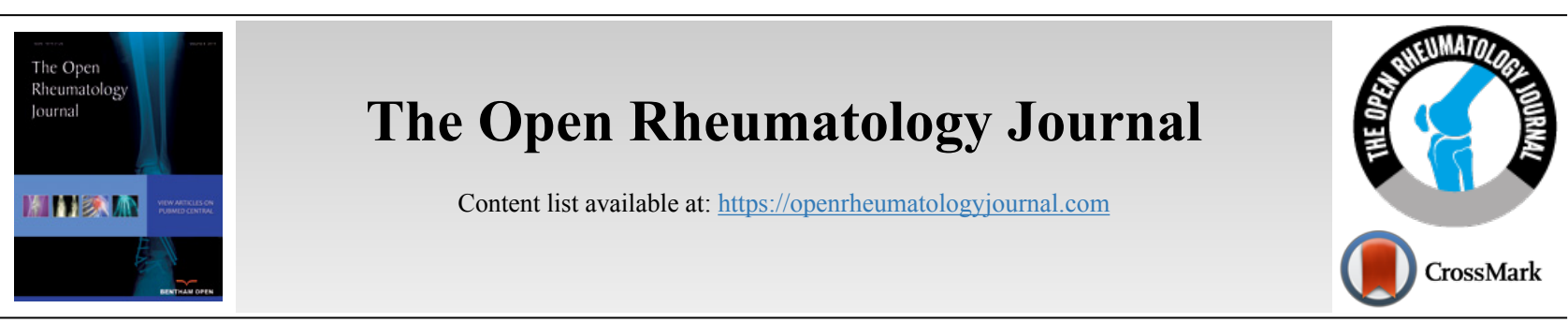

RESEARCH ARTICLE

\title{
Gene Polymorphism of XRCC1 in Systemic Lupus Erythematosus
}

\author{
Maysaa El Sayed Zaki ${ }^{1, *}$, Mostafa Abdelsalam², Sherine A. R. A. K Bassiouni ${ }^{3}$ and Asmaa Osman ${ }^{1}$ \\ ${ }^{\prime}$ Department of Clinical Pathology, Mansoura Faculty Medicine, Mansoura, Egypt \\ ${ }^{2}$ Nephrology Unit-Internal Medicine-Mansoura Faculty of Medicine, Mansoura, Egypt \\ ${ }^{3}$ Department of Physical Medicine, Rheumatology and Rehabilitation, Mansoura Faculty Medicine, Mansoura, Egypt
}

\begin{abstract}
:
Introduction:

There are debates about the role of the X-ray repair cross-complementation group 1 (XRCC1) Arg399Gln gene in the pathogenesis of Systemic Lupus Erythematosus (SLE).

Methods:

The study was a case-control study carried out on 100 recently diagnosed SLE patients compared to 100 control subjects. The study of XRCC1 Arg399Gln polymorphism was performed by a polymerase chain reaction and restriction fragment length polymorphism.

\section{Results and Discussion:}

A higher frequency of ' $G$ ' allele in SLE (38.5\%) versus control (32\%) was noticed; however, this difference was not statistically significant ( $\mathrm{p}=$ 0.174). Besides, a slightly higher frequency of G/G genotype was found in SLE ( $22 \%$ ) vs. control (12\%); again, this difference was not statistically significant $(\mathrm{p}=0.157)$. A statistically significantly higher proportion of arthritis, serositis, and thrombocytopenia was observed in the A/A genotype ( $\mathrm{p}=0.010,0.032$, and 0.036 , respectively). Furthermore, we noticed a statistically significant lower hemoglobin level in $\mathrm{G} / \mathrm{G}$ genotype ( $\mathrm{p}$ $=0.027$ ). Otherwise, there was no statistically significant difference between the three genotypes regarding other parameters: photosensitivity, malar rash, oral ulceration, ANA, anti-dsDNA antibody, anemia, leucopenia, neurologic manifestations, and all lab parameters except hemoglobin level. Similar results were reported previously.

According to genotype, in the study of Clinical and laboratory parameters in SLE patients, a statistically significantly higher proportion of arthritis, serositis, and thrombocytopenia was observed in the $\mathrm{A} / \mathrm{A}$ genotype $(\mathrm{p}=0.01,0.032$, and 0.036 respectively). Furthermore, we noticed a statistically significant lower hemoglobin level in $\mathrm{G} / \mathrm{G}$ genotype $(\mathrm{p}=0.027)$. These findings suggest a pathogenic connection between the seriousness of the defective DNA repair and the autoimmune severity; such connection is consistent with that found in several murine models. Additionally, negative regulation of the genes encoding the proteins involved in the NER pathway in SLE patients, specifically and XPC, has been found previously.

\section{Conclusion:}

The present study highlights the higher insignificant increase of G allele and GG genotype of XRCC1 399 gene in patients with SLE compared to healthy control. This increase was significantly associated with anemia in patients, which may reflect the aggravation of environmental risk factors to SLE associated with the reduced repair of DNA. Further longitudinal studies are required to validate the present findings.
\end{abstract}

Keywords: X-ray repair, Cross-complementation, Arg399Gln gene, Systemic lupus erythematosus, RFLP-PCR, DNA, B-cells activity.

\begin{tabular}{l|l|l|l} 
Article History & Received: November 1, 2020 & Revised: February 22, 2021 & Accepted: March 7, 2021
\end{tabular}

\section{INTRODUCTION}

Systemic Lupus Erythematosus (SLE) is an autoimmune disease that is more common in women than men at a young age with variation according to geographical region and socio-

\footnotetext{
* Address correspondence to this author at the Department of Clinical PathologyMansoura Faculty of Medicine, Egypt; Telephone: 0205022458877; E-mail: maysaazaki5@hotmail.com
}

economic status [1, 2]. SLE has 11 diagnostic criteria set forth by the American College of Rheumatology (ACR), including clinical and laboratory criteria [3, 4].

The pathogenesis of SLE may be associated with changes in autoantigens, leading to the production of autoantibodies besides genetics factors. The changes may be attributed to several factors such as chemicals, drugs, exposure to ultraviolet 
rays, and an increase in the reactive oxygen species that leads to damage in DNA $[5,6]$.

The mechanism known as DNA damage response and repair plays a vital role in the correction of DNA damage. The mechanisms contain multiple sensors, mediators, transducers, and effectors that manage the errors during the cell cycle and repair $[7,8]$. The studies have recognized that the uncorrected DNA damage leads to the accumulation of single-stranded DNAs (ssDNA) and double-stranded DNAs (dsDNA) in the cytoplasm of the cells. These nuclear remnants lead to the stimulation of interferon genes through the induction of the cGAS-STING -IRF3 pathway that leads to type I interferon [9 11]. Other mechanisms of DNA damage and imbalance in innate immunity are thought to be through the progression of the cell cycle through mitosis following DNA double-strand breaks formation that contributes to the formation of micronuclei leading to the immune activation system [12 - 14].

Some reports demonstrated an aberrant DNA repair system in patients with SLE $[15,16]$. There are reports suggesting that the deficient DNA repair and increased formation of endogenous DNA damage increase apoptosis and autoantibodies in patients with $\operatorname{SLE}[15,16]$.

There are two repair pathways for the correction of damaged DNA; these two pathways are base excision repair (BER) and nucleotide excision repair (NER) [17]. The X-ray repair cross-complementation group 1 (XRCC1) plays a central role in the BER pathway [18]. The damage produced by the free oxygen radicals, ionization, and alkylating agents are repaired by DNA repair protein [19]. The XRCC1 gene is a $33 \mathrm{~kb}$ gene located on chromosome 19q13.2-13.3 and has 17 exons [20]. There are three common types of polymorphisms among three hundred single nucleotide polymorphisms in the XRCC1 gene [21]. These three common types are Arg194Trp (exon six that leads to the substitution of $\mathrm{C}$ to $\mathrm{T}$ substitution, and rs1799782), Arg280His (exon nine that leads to the substitution of $\mathrm{G}$ to A substitution, and rs25489), and Arg399Gln (exon ten that leads to the substitution of G to A, and rs25487). The amino acid substitution is thought to alter the function of XRCC1 [22]. This change in protein biochemistry leads to the hypothesis that variant alleles may reduce kinetics repair, resulting in SLE susceptibility [23].

There are few reports about the XRCC1 Arg399Gln gene and SLE [24, 25]. Therefore, the present study aims to detect XRCC1 Arg399Gln gene polymorphism in recently diagnosed SLE patients compared to normal control subjects with polymerase chain reaction and restriction fragment length polymorphism (PCR-RFLP).

\section{MATERIALS AND METHODS}

The present study was a case-control study carried out on 100 recently diagnosed SLE patients compared to 100 control subjects recruited from Mansoura University hospital from March 2019 till January 2020. Patients are diagnosed according to the clinical signs and laboratory findings of autoantibodies as specified by the ACR [4]. Patients with other diseases, such as malignancies, rheumatoid arthritis, or other autoimmune disorders were excluded from the study. The control subjects are adults above 18 years old without autoimmune disorders and no family history of autoimmune disorders. Mansoura Ethical Committee approved the study (R.20.08.994), and approval consent was obtained from each participant.

\subsection{Extraction of DNA for XRCC1 Arg399GIn Detection by PCR-RFLP}

A five-milliliter blood sample overlaid on EDTA from each participant was subjected to DNA extraction by specific extraction QIAamp DNA Blood Mini Kit (Qiagen- 19300 Germantown Road Germantown, MD 20874). The extraction of DNA depended upon the use of silica membrane DNA purification.

\subsection{Polymerase Chain Reaction and Restriction Fragment Length Polymorphism}

The primers used for the amplification of XRCC1 (Arg399Gln) were 5/-TTGTGCTTTCTCTGTGTCCA-/3 and 5/-TCCTCCAGCCTTTTCTGATA-/3. The amplification was carried out using 20 microliters of ready-to-use amplification mixture Qiagen (Thermofisher-USA) with added 100 nanograms of the extracted DNA and 20 pmol of each primer. The amplification reaction procedures included initial denaturation at $94^{\circ} \mathrm{C}$ for $5 \mathrm{~min}$, followed by 35 cycles at $94^{\circ} \mathrm{C}$ for $45 \mathrm{~s}, 58^{\circ} \mathrm{C}$ for $45 \mathrm{~s}$ and $72^{\circ} \mathrm{C}$ for $1 \mathrm{~min}$. The final extension was done at $72^{\circ} \mathrm{C}$ for $10 \mathrm{~min}$. The amplification products were then subjected to the digestion restriction enzyme HpaII (New England BioLabs, USA) for 2 hours at $37^{\circ} \mathrm{C}$ and electrophoresed on a $2.5 \%$ agarose gel stained with ethidium bromide. The amplification products were two bands at 240 and 375 for GG genotype, 375 and 615 for AG genotype, and 615 for AA genotype [26].

\subsection{Statistical Analysis}

Data were entered and analyzed using IBM-SPSS software (IBM Corp. Released 2017. IBM SPSS Statistics for Windows, Version 25.0. Armonk, NY: IBM Corp.). Qualitative data were expressed as frequency and percentage. Quantitative data were initially tested for normality using Shapiro-Wilk's test with normally distributed data if $\mathrm{p}>0.05$. The presence of outliers was tested by inspecting the boxplots. Accordingly, quantitative data in this study were expressed as median $\left(25^{\text {th }}\right.$ percentile- $75^{\text {th }}$ percentile). Qualitative data were compared by Chi-Square or Fisher's exact test. Z-test with Bonferroni method to adjust $p$-values were used when comparing column proportions. Quantitative data between two groups were compared by the Mann-Whitney U test and between three groups by Kruskal-Wallis H-test. SNPStats is a web tool that was used for single nucleotide polymorphisms (SNP) analysis (https://www.snpstats.net/start.htm). For any of the used tests, results were considered statistically significant if $p$-value $\leq$ 0.05 . Appropriate charts were used to present the results whenever needed graphically.

\section{RESULTS}

\subsection{Demographic Data and Laboratory Parameters in the Study Groups}

This study involved 200 participants divided into two age 
and sex-matched groups: Group 1 (SLE group) comprising 100 SLE patients (43 males and 57 females), their median age 35 years (interquartile range (IQR) 24-46.5); Group 2 (control group) comprising 100 healthy subjects (39 males and 61 females), their median age 34 years (IQR: 24-46) (Table 1).

Regarding the laboratory investigations, hematologic parameters including hemoglobin level, platelet count, and total leucocytic count (TLC) in SLE patients were found to be statistically significantly lower than that of controls $(\mathrm{p}=0.003$, $<0.001$, and $<0.001$, respectively). On the other hand, a statistically significant higher C3 level in SLE patients $v s$. controls was discovered $(p=0.007)$. Meanwhile, there was no statistically significant difference between the two groups regarding serum creatinine, $\mathrm{C} 4 \mathrm{level}$, and 24-hours urine protein, as illustrated in Table $\mathbf{1}$.

\subsection{Distribution of the XRCC1 Arg399GIn Alleles and Genotypes in SLE Patients and Controls}

A slightly higher frequency of the ' $G$ ' allele in SLE $(38.5 \%)$ vs. control $(32 \%)$ was noticed; however, this difference was not statistically significant $(\mathrm{P}=0.174)$. Besides, a slightly higher frequency of G/G genotype was found in SLE $(22 \%)$ vs. control (12\%). Again, this difference was not statistically significant $(\mathrm{P}=0.157)$ (Table 2).

\subsection{SNP Association with SLE}

As shown in Table 3, the recessive model could be the best inheritance model (the model with the lowest P, Akaiki Information Criterion (AIC), and Bayesian Information Criterion (BIC) values). Performing SNP exact test for HardyWeinberg equilibrium revealed that the $\mathrm{p}$-value for the control group was 0.49 (Insignificant), which means that the requirement of Hardy-Weinberg equilibrium exists.

Table 1. Comparisons between the two groups regarding the demographic data and laboratory parameters.

\begin{tabular}{|c|c|c|c|c|}
\hline \multirow{2}{*}{ Parameter } & \multirow[t]{2}{*}{ Group 1} & \multirow[t]{2}{*}{ Group 2} & \multicolumn{2}{|c|}{ Test of significance } \\
\hline & & & $\mathrm{Z} / \chi^{2}$ & P-value \\
\hline $\mathrm{N}$ & 100 & 100 & & \\
\hline $\begin{array}{c}\text { Sex } \\
\text { Male } \\
\text { Female }\end{array}$ & $\begin{array}{l}43 \\
57\end{array}$ & $\begin{array}{l}39 \\
61\end{array}$ & $\chi^{2}=0.331$ & 0.565 \\
\hline Age (years) (range-median) & $35(24-46.5)$ & $34(24-46)$ & $Z=-0.540$ & 0.590 \\
\hline Hemoglobin level (g/dL) & $12(10.5-13)$ & $12(11.9-13.7)$ & $Z=-3.021$ & 0.003 \\
\hline Platelet count & $150(82-177)$ & $178(140-228)$ & $Z=-4.966$ & $<0.001$ \\
\hline Total leucocytic count & $5.5(4-7)$ & $7.2(7.0-8.1)$ & $Z=-7.004$ & $<0.001$ \\
\hline Serum creatinine $(\mathrm{mg} / \mathrm{dL})$ & $0.9(0.9-1.0)$ & $0.9(0.9-1.0)$ & $Z=-0.029$ & 0.976 \\
\hline $\mathrm{C} 3(\mathrm{mg} / \mathrm{dL})$ & $123(90-155)$ & $100(83.5-128)$ & $Z=-2.718$ & 0.007 \\
\hline $\mathrm{C} 4(\mathrm{mg} / \mathrm{dL})$ & $31(22-40)$ & $31(24-39.8)$ & $Z=-0.198$ & 0.843 \\
\hline 24-hour urinary protein & $70(64-78)$ & $70(61-87)$ & $Z=-0.340$ & 0.734 \\
\hline
\end{tabular}

Data expression [test of significance]: $\mathrm{N}$ [Chi-Square test] for sex and median $\left(25^{\text {th }}-75^{\text {th }}\right.$ percentiles $)$ [Mann-Whitney U-test] for quantitative data

Table 2. Distribution of alleles and genotypes of XRCC1 Arg399GIn gene in the two groups.

\begin{tabular}{|c|c|c|c|c|}
\hline \multirow{2}{*}{ Parameter } & Group 1 & Group 2 & \multicolumn{2}{|c|}{ Test of significance } \\
\cline { 3 - 5 } & & & $\chi^{2}$ & P-value \\
\hline N of participants & 100 & 100 & 1.851 & 0.174 \\
\hline Alleles & $123(61.5 \%)$ & $136(68 \%)$ & & \\
'G' allele $G$ ' allele & $77(38.5 \%)$ & $64(32 \%)$ & & 0.157 \\
\hline Genotypes & 45 & 48 & 3.709 & \\
A/A & 33 & 40 & & \\
A/G & 22 & & & \\
G/G & & & & \\
\hline
\end{tabular}

Data expression [test of significance]: N (\%) [Chi-Square test].

Table 3. SNP association with SLE

\begin{tabular}{|c|c|c|c|c|c|c|c|c|}
\hline Model & Genotype & Group 1 & Group 2 & OR & 95\% CI & P-value & AIC & BIC \\
\hline Codominant & $\mathrm{A} / \mathrm{A}$ & 45 & 48 & $\mathrm{R}$ & $\mathrm{R}$ & 0.150 & 279.5 & 289.4 \\
& $\mathrm{~A} / \mathrm{G}$ & 33 & 40 & 0.88 & $0.48-1.63$ & \\
& $\mathrm{G} / \mathrm{G}$ & 22 & 12 & 1.96 & $0.87-4.41$ & \\
& $\mathrm{~A} / \mathrm{A}$ & 45 & 48 & $\mathrm{R}$ & $\mathrm{R}$ & 0.670 & 281.1 & 287.7 \\
& $\mathrm{~A} / \mathrm{G}-\mathrm{G} / \mathrm{G}$ & 55 & 52 & 1.13 & $0.65-1.97$ & \\
\hline
\end{tabular}




\begin{tabular}{|c|c|c|c|c|c|c|c|c|}
\hline Recessive & $\begin{array}{c}\mathrm{A} / \mathrm{A}-\mathrm{A} / \mathrm{G} \\
\mathrm{G} / \mathrm{G}\end{array}$ & $\begin{array}{l}78 \\
22\end{array}$ & $\begin{array}{l}88 \\
12\end{array}$ & $\begin{array}{c}\mathrm{R} \\
2.07\end{array}$ & $\begin{array}{c}\mathrm{R} \\
0.96-4.45\end{array}$ & 0.058 & 277.7 & 284.3 \\
\hline Overdominant & $\begin{array}{c}\mathrm{A} / \mathrm{A}-\mathrm{G} / \mathrm{G} \\
\mathrm{A} / \mathrm{G}\end{array}$ & $\begin{array}{l}67 \\
33\end{array}$ & $\begin{array}{l}60 \\
40\end{array}$ & $\begin{array}{c}\mathrm{R} \\
0.74\end{array}$ & $\begin{array}{c}\mathrm{R} \\
0.41-1.32\end{array}$ & 0.300 & 280.2 & 286.8 \\
\hline Log-additive & - & - & - & 1.27 & $0.87-1.85$ & 0.210 & 279.7 & 286.3 \\
\hline
\end{tabular}

$\mathrm{R}=$ reference category. $\mathrm{OR}=$ Odds ratio. $\mathrm{CI}=$ Confidence interval. $\mathrm{AIC}=\mathrm{Akaiki}$ Information Criterion. $\mathrm{BIC}=$ Bayesian Information Criterion.

\subsection{Clinical and Laboratory Parameters in SLE Patients According to Genotype}

A statistically significantly higher proportion of arthritis, serositis, and thrombocytopenia was observed in the A/A genotype $(\mathrm{p}=0.010,0.032$, and 0.036 , respectively). Furthermore, we noticed a statistically significant lower hemoglobin level in $\mathrm{G} / \mathrm{G}$ genotype $(\mathrm{p}=0.027)$. Otherwise, there was no statistically significant difference between the three genotypes regarding other parameters; photosensitivity, malar rash, oral ulceration, ANA, anti-dsDNA antibody, anemia, leucopenia, neurologic manifestations, and all lab parameters except hemoglobin level (Table 4).
Table 5 illustrates the results of running binary logistic regression to ascertain the effects of the male sex, G/G genotype, and age on the likelihood that participants (SLE cases) will exhibit anemia. The model was statistically significant $\left(\chi^{2}[3]=19.091, \mathrm{P}<0.001\right)$. The model explains $23.2 \%$ of the variance in anemia (Nagelkerke $\mathrm{R}^{2}=0.232$ ) and correctly classifies $70 \%$ of cases. Of the three-predictor variables, male sex and $\mathrm{G} / \mathrm{G}$ genotypes were statistically significant independent predictors of anemia in SLE cases. Male sex and G/G genotype have 4.6- and 3.5-times higher odds that SLE cases will exhibit anemia, respectively.

Table 4. Clinico-laboratory parameters in SLE patients according to genotype.

\begin{tabular}{|c|c|c|c|c|c|}
\hline \multirow{2}{*}{ Parameter } & \multicolumn{5}{|c|}{ XRCC1 Arg399GIn gene } \\
\hline & $\mathbf{A} / \mathbf{A}$ & $\mathbf{A} / \mathbf{G}$ & G/G & Total & P-value \\
\hline $\mathrm{N}$ & 45 & 33 & 22 & 100 & \\
\hline Photosensitivity & $30(68.2 \%)$ & $19(57.6 \%)$ & $15(68.2 \%)$ & 64 & 0.582 \\
\hline Malar rash & $32(71.1 \%)$ & $28(84.8 \%)$ & $13(59.1 \%)$ & 73 & 0.101 \\
\hline Arthritis & $25(55.6 \%) \mathrm{a}$ & $7(21.2 \%) b$ & $9(40.9 \%) \mathrm{a}, \mathrm{b}$ & 41 & 0.010 \\
\hline Serositis & $10(22.2 \%) \mathrm{a}$ & $7(21.2 \%) \mathrm{a}, \mathrm{b}$ & $0(0 \%) \mathrm{b}$ & 17 & $0.032 *$ \\
\hline Oral ulceration & $23(51.1 \%)$ & $22(66.7 \%)$ & $10(45.5 \%)$ & 55 & 0.235 \\
\hline Antinuclear antibody (ANA) & $19(42.2 \%)$ & $13(39.4 \%)$ & $9(40.9 \%)$ & 41 & 0.969 \\
\hline Anti-dsDNA antibody & $29(64.4 \%)$ & $15(45.5 \%)$ & $12(54.5 \%)$ & 56 & 0.245 \\
\hline Anemia & $22(48.9 \%)$ & $14(42.4 \%)$ & $16(72.7 \%)$ & 52 & 0.075 \\
\hline Thrombocytopenia & $28(62.2 \%) \mathrm{a}$ & $12(36.4 \%) \mathrm{b}$ & $8(36.4 \%) b$ & 48 & 0.036 \\
\hline Leucopenia & $3(6.7 \%)$ & $4(12.1 \%)$ & $2(9.1 \%)$ & 9 & $0.746^{*}$ \\
\hline Neurologic manifestations & $6(13.3 \%)$ & $6(18.2 \%)$ & $7(31.8 \%)$ & 19 & $0.217^{*}$ \\
\hline Hemoglobin level (g/dL) & $12(11-13)$ & $12(10.5-13.7)$ & $10.5(9.0-12.6)$ & $12(10.5-13)$ & $0.027^{s}$ \\
\hline Platelet count & $129(78-170)$ & $167(134-182)$ & $163(90-175)$ & $150(82-177)$ & $0.076^{\mathrm{s}}$ \\
\hline Total leucocytic count & $6(4.3-7)$ & $5.7(4.0-7.0)$ & $4.0(4.0-6.6)$ & $5.5(4.0-7.0)$ & $0.172^{\mathrm{s}}$ \\
\hline Serum creatinine & $0.9(0.8-1.0)$ & $0.9(0.9-1.0)$ & $0.9(0.78-1.0)$ & $0.9(0.9-1.0)$ & $0.474^{\mathrm{s}}$ \\
\hline $\mathrm{C} 3$ (mg/dL) & $140(90-158)$ & $120(90-147)$ & $110(83.8-147.8)$ & $123(90-155)$ & $0.402^{\mathrm{s}}$ \\
\hline $\mathrm{C} 4$ (mg/dL) & $30(22.5-39.5)$ & $33(22.5-43)$ & $29.5(21-35)$ & $31(22-40)$ & $0.223^{\mathrm{s}}$ \\
\hline 24-hour urinary protein & $70(60.5-80)$ & $70(65-78.5)$ & $70(64.3-75.5)$ & $70(64-78)$ & $0.747^{\mathrm{s}}$ \\
\hline
\end{tabular}

Data expression [Test of significance]: N (\%) [Chi-Square test or *Fisher's exact test] or Median $\left(25^{\text {th }}\right.$ percentile-75 ${ }^{\text {th }}$ percentile) $[\text { Kruskal-Wallis H-test }]^{\text {s }}$

Table 5. Predictors of the likelihood of anemia in SLE cases.

\begin{tabular}{|c|c|c|c|c|c|c|}
\hline Predictor & Univariate & - & - & Multivariate & - & - \\
\hline & P-value & $\mathrm{COR}$ & $95 \% \mathrm{CI}$ & P-value & OR & $95 \% \mathrm{CI}$ \\
\hline $\begin{array}{c}\text { Sex } \\
\text { Female } \\
\text { Male }\end{array}$ & 0.001 & $\begin{array}{c}\mathrm{R} \\
4.8\end{array}$ & $\begin{array}{c}\mathrm{R} \\
2.0-11.6\end{array}$ & 0.002 & $\begin{array}{c}\mathrm{R} \\
4.6\end{array}$ & $\begin{array}{c}\mathrm{R} \\
1.7-11.95\end{array}$ \\
\hline Age (years) & 0.049 & 1.029 & $1.0-1.06$ & 0.480 & 1.011 & $0.98-1.044$ \\
\hline $\begin{array}{c}\text { Genotype } \\
\text { A/A-A/G } \\
\text { G/G }\end{array}$ & 0.032 & $\begin{array}{c}\mathrm{R} \\
3.1\end{array}$ & $\begin{array}{c}\mathrm{R} \\
1.1-8.8\end{array}$ & 0.028 & $\begin{array}{c}\mathrm{R} \\
3.5\end{array}$ & $\begin{array}{c}\mathrm{R} \\
1.14-10.56\end{array}$ \\
\hline
\end{tabular}

$\mathrm{COR}=$ Crude odds ratio. $\mathrm{OR}=$ Odds ratio. $\mathrm{CI}=$ Confidence interval. $\mathrm{R}=$ reference category. P-value: Binary logistic regression. 


\section{DISCUSSION}

The defects in the repair of DNA damage that are associated with exposure to ionizing radiation, active oxygen radicals, and alkylating agents might be implicated in the development of SLE [27]. Among the proteins known for their ability to repair DNA damage is the X-ray crosscomplementing defective repair in Chinese hamster cells 1 (XRCC1) protein. The gene of this protein presents on the long arm of chromosome 19 (19q13.2). This gene contains 17 exons and encodes a protein composed of 633 amino acids known by the same name [28, 29]. The function of this DNA repair protein is the effective repair of the damage attributed to active oxygen, ionization, and alkylating agents. There are data suggesting the increased susceptibility to SLE associated with the XRCC1 polymorphisms Arg399Gln, Arg 194Trp, and Arg280His [30]. It is suggested that polymorphisms may lead to the amino acid changes at preserved regions that alter the functions of these genes [30].

In the study of XRCC1 Arg399GIn gene polymorphism, there was a higher frequency of $G$ allele and GG genotype in our patients, though this increase was statistically insignificant ( $p=0.174, p=0.157$ respectively). These results are consistent with previous studies that reported an insignificant increase in the frequency of the XRCC1 $399 \mathrm{Gln} / \mathrm{Gln}$ genotype and 399 Gln/Arg heterozygous in SLE patients [31,32]. A recent study from Egypt reported similar findings in lower sample size comprised of fifty patients [33]. However, in a previous study among the Taiwanese Han Chinese population, the polymorphism at codon 399 of the XRCC1 gene was associated with the pathogenesis of SLE [34]. A meta-analysis study showed an association between the Arg399Gln polymorphism and SLE in Asians and Caucasians with protecting role for $\mathrm{A}$ allele in Caucasian and $\mathrm{G}$ allele as a risk factor for SLE, while the A allele as a risk factor for Asian population [35]. These variations in the effect of the XRCC1 Arg399Gln genotypes on the susceptibility of SLE and clinical manifestations in different ethnicities may be explained by the variations in the studied sample size or the racial heterogeneity $[36,37]$.

There is a suggestion that the XRCC1 399 Gln polymorphic variant plays a role as a genetic modifier for raising the formation of DNA adducts and DNA damage in individuals exposed to aflatoxin B1, cigarette smoke, 1,3butadiene, vinyl chloride metabolites, or styrene [37, 38].

In the present study, no association was observed among the XRCC1 Arg399Gln polymorphism, ANA and anti-dsDNA antibody. Similar results were reported previously [39].

According to genotype, in the study of Clinical and laboratory parameters in SLE patients, a statistically significantly higher proportion of arthritis, serositis, and thrombocytopenia was observed in the A/A genotype ( $p$ $=0.010,0.032$, and 0.036, respectively). Furthermore, we noticed a statistically significant lower hemoglobin level in $\mathrm{G} / \mathrm{G}$ genotype $(\mathrm{p}=0.027)$. These findings suggest a pathogenic connection between the seriousness of the defective DNA repair and the autoimmune severity; such connection is consistent with that found in several murine models.
Additionally, negative regulation of the genes encoding the proteins involved in the NER pathway in SLE patients, specifically DDB1, ERCC2, XPA, and XPC, has been found [40].

The present study's distinguished findings were that the male gender and G/G genotype have 4.6- and 3.5-times higher odds with exhibit anemia, respectively. This may be a manifestation of the enhanced effect of some environmental factors such as exposure to UV as a cofactor for DNA damage repair defects associated with $G$ allele genotype in the Caucasian population, associated with the severity of some autoimmune manifestations [40]. The statistical analysis performing SNP exact test for Hardy-Weinberg equilibrium revealed that the $\mathrm{p}$-value for the control group was 0.49 (Insignificant), which means that the requirement of HardyWeinberg equilibrium exists.

In one Polish study, patients with the XRCC1 Gln/Gln or Arg/Gln genotypes had a significantly higher risk of getting a malar rash and photosensitivity [39]. Similarly, in the Taiwanese Han Chinese population, photosensitivity or malar rash was associated with the XRCC1 Arg/Gln heterozygotes [34]. Moreover, the XRCC1 Arg/Gln heterozygote has also been associated with hematologic and arthritis manifestations as well as the presence of ANA antibodies [34]. In the study of Basi et al. on SLE patients, he found that the XRCC1 Arg399Gln polymorphism was significantly associated with the presence of an anti-dsDNA antibody. Moreover, the coexistence of two DNA repair polymorphic sites was associated with neuropsychiatric features, antiphospholipid syndrome, and anti-dsDNA antibody in SLE patients [29]. These variations in the effect of the XRCC1 Arg399Gln genotypes on SLE and clinical manifestations in different ethnicities may be explained by the racial heterogeneity or size of the studied groups and the different populations' exposure to various environmental chemicals interacting with the XRCC1 Arg399Gln genotypes [41].

\section{CONCLUSION}

The present study highlights the higher insignificant increase of G allele and GG genotype of XRCC1 399 gene in patients with SLE compared to healthy control. This increase was significantly associated with anemia in patients, reflecting the aggravation of environmental risk factors to SLE associated with the reduced repair of DNA. Further longitudinal studies are required to validate the present findings.

\section{ETHICS APPROVAL AND CONSENT TO PARTI- CIPATE}

This study was approved by the Mansoura Ethical Committee, Mansoura, Egypt under ethical approval no. (R.20.08.994).

\section{HUMAN AND ANIMAL RIGHTS}

No Animals were used in this research. All human research procedures followed were in accordance with the ethical standards of the committee responsible for human experimentation (institutional and national), and with the Helsinki Declaration of 1975, as revised in 2013. 


\section{CONSENT FOR PUBLICATION}

Informed consent was obtained from all the participants when they were enrolled.

\section{AVAILABILITY OF DATA AND MATERIALS}

The authors confirm that the data supporting the findings of this study are available within the article.

\section{FUNDING}

None.

\section{CONFLICT OF INTEREST}

The authors declare no conflict of interest, financial or otherwise

\section{ACKNOWLEDGEMENTS}

Declared none.

\section{REFERENCES}

[1] Manson JJ, Rahman A. Systemic lupus erythematosus. Orphanet J Rare Dis 2006; $1: 6$

[http://dx.doi.org/10.1186/1750-1172-1-6] [PMID: 16722594]

[2] Moser KL, Kelly JA, Lessard CJ, Harley JB. Recent insights into the genetic basis of systemic lupus erythematosus. Genes Immun 2009; 10(5): 373-9.

[http://dx.doi.org/10.1038/gene.2009.39] [PMID: 19440199]

[3] Sahebari M, Hatef MR, Rezaieyazdi Z, Abbasi M, Abbasi B, Mahmoudi M. Correlation between serum levels of soluble Fas (CD95/Apo-1) with disease activity in systemic lupus erythematosus patients in Khorasan, Iran. Arch Iran Med 2010; 13(2): 135-42. [PMID: 20187668]

[4] Petri M, Orbai AM, Alarcón GS, et al. Derivation and validation of the Systemic Lupus International Collaborating Clinics classification criteria for systemic lupus erythematosus. Arthritis Rheum 2012; 64(8): 2677-86.

[http://dx.doi.org/10.1002/art.34473] [PMID: 22553077]

[5] Kamen DL. Environmental influences on systemic lupus erythematosus expression. Rheum Dis Clin North Am 2014; 40(3): 401-412, vii.

[http://dx.doi.org/10.1016/j.rdc.2014.05.003] [PMID: 25034153]

[6] Jönsen A, Bengtsson AA, Nived O, Truedsson L, Sturfelt G. Geneenvironment interactions in the aetiology of systemic lupus erythematosus. Autoimmunity 2007; 40(8): 613-7. [http://dx.doi.org/10.1080/08916930701511051] [PMID: 18075795]

[7] Jackson SP, Bartek J. The DNA-damage response in human biology and disease. Nature 2009; 461(7267): 1071-8.

[http://dx.doi.org/10.1038/nature08467] [PMID: 19847258]

[8] Pateras IS, Havaki S, Nikitopoulou X, et al. The DNA damage response and immune signaling alliance: Is it good or bad? Nature decides when and where. Pharmacol Ther 2015; 154: 36-56.

[http://dx.doi.org/10.1016/j.pharmthera.2015.06.011] [PMID: 26145166]

[9] Souliotis VL, Sfikakis PP. Increased DNA double-strand breaks and enhanced apoptosis in patients with lupus nephritis. Lupus 2015; 24(8): 804-15.

[http://dx.doi.org/10.1177/0961203314565413] [PMID: 25542905]

[10] Souliotis VL, Vougas K, Gorgoulis VG, Sfikakis PP. Defective DNA repair and chromatin organization in patients with quiescent systemic lupus erythematosus. Arthritis Res Ther 2016; 18(1): 182

[http://dx.doi.org/10.1186/s13075-016-1081-3] [PMID: 27492607]

[11] Mackenzie KJ, Carroll P, Lettice L, et al. Ribonuclease H2 mutations induce a cGAS/STING-dependent innate immune response. EMBO J 2016; 35(8): 831-44.

[http://dx.doi.org/10.15252/embj.201593339] [PMID: 26903602]

[12] Mackenzie KJ, Carroll P, Martin CA, et al. cGAS surveillance of micronuclei links genome instability to innate immunity. Nature 2017; 548(7668): 461-5.

[http://dx.doi.org/10.1038/nature23449] [PMID: 28738408]

[13] Harding SM, Benci JL, Irianto J, Discher DE, Minn AJ, Greenberg
RA. Mitotic progression following DNA damage enables pattern recognition within micronuclei. Nature 2017; 548(7668): 466-70. [http://dx.doi.org/10.1038/nature23470] [PMID: 28759889]

[14] Bartsch K, Knittler K, Borowski C, et al. Absence of RNase H2 triggers generation of immunogenic micronuclei removed by autophagy. Hum Mol Genet 2017; 26(20): 3960-72.

[http://dx.doi.org/10.1093/hmg/ddx283] [PMID: 29016854]

[15] Mistry P, Kaplan MJ. Cell death in the pathogenesis of systemic lupus erythematosus and lupus nephritis. Clin Immunol 2017; 185: 59-73. [http://dx.doi.org/10.1016/j.clim.2016.08.010] [PMID: 27519955]

[16] Lo MS, Tsokos GC. Recent developments in systemic lupus erythematosus pathogenesis and applications for therapy. Curr Opin Rheumatol 2018; 30(2): 222-8.

[http://dx.doi.org/10.1097/BOR.0000000000000474]

[PMID: 29206660]

[17] Svilar D, Goellner EM, Almeida KH, Sobol RW. Base excision repair and lesion-dependent subpathways for repair of oxidative DNA damage. Antioxid Redox Signal 2011; 14(12): 2491-507. [http://dx.doi.org/10.1089/ars.2010.3466] [PMID: 20649466]

[18] Hung RJ, Hall J, Brennan P, Boffetta P. Genetic polymorphisms in the base excision repair pathway and cancer risk: a HuGE review. Am J Epidemiol 2005; 162(10): 925-42.

[http://dx.doi.org/10.1093/aje/kwi318] [PMID: 16221808]

[19] Caldecott KW. XRCC1 and DNA strand break repair. DNA Repair (Amst) 2003; 2(9): 955-69.

[http://dx.doi.org/10.1016/S1568-7864(03)00118-6]

[PMID: 12967653]

[20] Thompson LH, West MG. XRCC1 keeps DNA from getting stranded. Mutat Res 2000; 459(1): 1-18.

[http://dx.doi.org/10.1016/S0921-8777(99)00058-0] [PMID: 10677679]

[21] Trabulus S, Guven GS, Altiparmak MR, et al. DNA repair XRCC1 Arg399Gln polymorphism is associated with the risk of development of end-stage renal disease. Mol Biol Rep 2012; 39(6): 6995-7001. [http://dx.doi.org/10.1007/s11033-012-1529-8] [PMID: 22302399]

[22] Liu F, Li B, Wei Y, et al. XRCC1 genetic polymorphism Arg399Gln and hepatocellular carcinoma risk: A meta-analysis. Liver Int 2011; 31(6): 802-9.

[http://dx.doi.org/10.1111/j.1478-3231.2011.02508.x] [PMID: 21645210]

[23] Ryu RA, Tae K, Min HJ, et al. XRCC1 polymorphisms and risk of papillary thyroid carcinoma in a Korean sample. J Korean Med Sci 2011; 26(8): 991-5.

[http://dx.doi.org/10.3346/jkms.2011.26.8.991] [PMID: 21860547]

[24] Salimi S, Mohammadoo-Khorasani M, Tabatabai E, Sandoughi M, Zakeri Z, Naghavi A. XRCC1 Arg399Gln and Arg194Trp polymorphisms and risk of systemic lupus erythematosus in an Iranian population: A pilot study. BioMed Res Int 2014; 2014492956 [http://dx.doi.org/10.1155/2014/492956] [PMID: 24971336]

[25] Kamenarska Z, Hristova M, Dodova R, et al. XRCC1 variants do not represent a risk for dermatomyositis and systemic lupus erythematosus in Bulgarian patients. Acta Dermatovenerol Alp Panonica Adriat 2019; 28(4): 149-52.

[http://dx.doi.org/10.15570/actaapa.2019.36] [PMID: 31855267]

[26] Choudhury JH, Choudhury B, Kundu S, Ghosh SK. Combined effect of tobacco and DNA repair genes polymorphisms of XRCC1 and XRCC2 influence high risk of head and neck squamous cell carcinoma in northeast Indian population. Med Oncol 2014; 31(8): 67.

[http://dx.doi.org/10.1007/s12032-014-0067-8] [PMID: 24958516]

[27] Fu D, Calvo JA, Samson LD. Balancing repair and tolerance of DNA damage caused by alkylating agents. Nat Rev Cancer 2012; 12(2): 104-20.

[http://dx.doi.org/10.1038/nrc3185] [PMID: 22237395]

[28] Thacker J, Zdzienicka MZ. The XRCC genes: expanding roles in DNA double-strand break repair. DNA Repair (Amst) 2004; 3(8-9): 1081-90.

[http://dx.doi.org/10.1016/j.dnarep.2004.04.012] [PMID: 15279796]

[29] Bassi C, Xavier Dj, Palomino G, et al. Efficiency of the DNA repair and polymorphisms of the XRCC1, XRCC3 and XRCC4 DNA repair genes in systemic lupus erythematosus. Lupus 2008; 17(11): 988-95. [http://dx.doi.org/10.1177/0961203308093461] [PMID: 18852222]

[30] Zhang MM, Qi M, Che DF, et al. Correlation between single nucleotide polymorphism of the DNA repair gene XRCC1 and systemic lupus erythematosus. Chin J Clin Lab Sci 2011; 29: 115-7.

[31] Peng M, Zhou X, Ding X, et al. Association of XRCC1 Arg399Gln and Arg194Trp polymorphisms with susceptibility to multiple autoimmune diseases: A meta-analysis. Rheumatol Int 2017; 37(3): 
435-44.

[http://dx.doi.org/10.1007/s00296-016-3585-1] [PMID: 27812739]

[32] Leite Da Silva CA, Galera MF, Festi RR, et al. Association of polymorphisms in the DNA repair genes XRCC1 and XRCC3 with systemic lupus erythematosus. Open Rheumatol J 2019; 13: 15-2. [http://dx.doi.org/10.2174/1874312901913010015]

[33] Mortada MA, Zidan HE, Abdelsalam NA, et al. Gene XRCC1Arg399Gln polymorphism and its genotype variations: Clinical associations in Egyptian systemic lupus erythematosus patients. Egypt Rheumatol Rehabil 2020; 47: 2 [http://dx.doi.org/10.1186/s43166-020-00009-2]

[34] Lin YJ, Wan L, Huang CM, et al. Polymorphisms in the DNA repair gene $\mathrm{XRCC} 1$ and associations with systemic lupus erythematosus risk in the Taiwanese Han Chinese population. Lupus 2009; 18(14): 1246-51.

[http://dx.doi.org/10.1177/0961203309345777] [PMID: 19880550]

[35] Zhang MY, Yang XK, Lv TT, et al. Meta-analysis of associations between XRCC1 gene polymorphisms and susceptibility to systemic lupus erythematosus and rheumatoid arthritis. Int J Rheum Dis 2018; 21(1): 179-85.

[http://dx.doi.org/10.1111/1756-185X.12966] [PMID: 28198159]

[36] Sarzi-Puttini P, Atzeni F, Iaccarino L, Doria A. Environment and systemic lupus erythematosus: An overview. Autoimmunity 2005;
38(7): 465-72.

[http://dx.doi.org/10.1080/08916930500285394] [PMID: 16373251]

[37] Jönsen A, Bengtsson AA, Nived O, Truedsson L, Sturfelt G. Geneenvironment interactions in the aetiology of systemic lupus erythematosus. Autoimmunity 2007; 40(8): 613-7.

[http://dx.doi.org/10.1080/08916930701511051] [PMID: 18075795]

[38] Li Y, Long C, Lin G, et al. Effect of the XRCC1 codon 399 polymorphism on the repair of vinyl chloride metabolite-induced DNA damage. J Carcinog 2009; 8: 14

[http://dx.doi.org/10.4103/1477-3163.56290] [PMID: 19822958]

[39] Warchoł T, Mostowska A, Lianeri M, Lacki JK, Jagodziński PP. XRCC1 Arg399Gln gene polymorphism and the risk of systemic lupus erythematosus in the Polish population. DNA Cell Biol 2012; 31(1): 50-6.

[http://dx.doi.org/10.1089/dna.2011.1246] [PMID: 21682595]

[40] Mireles-Canales MP, González-Chávez SA, Quiñonez-Flores CM, León-López EA, Pacheco-Tena C. DNA damage and deficiencies in the mechanisms of its repair: Implications in the pathogenesis of systemic lupus erythematosus. J Immunol Res 2018; 20188214379 [http://dx.doi.org/10.1155/2018/8214379] [PMID: 30116756]

[41] Jo" nsen A, Bengtsson AA, Nived O, Truedsson L and Sturfelt G. Gene-environment interactions in the aetiology of systemic lupus erythematosus. Autoimmunity 2007; 40: 613-7. [http://dx.doi.org/10.1080/08916930701511051]

\section{(C) 2021 Zaki et al.}

This is an open access article distributed under the terms of the Creative Commons Attribution 4.0 International Public License (CC-BY 4.0), a copy of which is available at: https://creativecommons.org/licenses/by/4.0/legalcode. This license permits unrestricted use, distribution, and reproduction in any medium, provided the original author and source are credited. 